\title{
Microvessel density assessment in canine mammary carcinomas as a predictive factor for metronomic chemotherapy
}

\section{Mensuração da densidade microvascular em carcinomas mamários caninos como fator preditivo à quimioterapia metronômica}

\author{
Analy Ramos Mendes Ferrari ${ }^{1 *}$; Heitor Flavio Ferrari ${ }^{2}$; Vinicius Soares Carreira ${ }^{3}$; \\ Edenilson Doná Frigério ${ }^{4}$; Maria Cecília Rui Luvizotto ${ }^{5}$; \\ Alexandre Lima de Andrade ${ }^{5}$
}

\begin{abstract}
The canine mammary tumor is the neoplasia that most commonly affects intact female dogs (not spayed) in routine veterinary practice. Canine mammary tumor therapy is a challenge because only few effective treatments have been described for high-grade tumors in veterinary medicine. One such therapeutic option that slows down tumor growth is metronomic chemotherapy (MC), a therapeutic modality that acts by decreasing tumor angiogenesis. Quantification of intratumoral microvessel density (MVD) has been proposed as a means to evaluate the effectiveness of MC in human and canine tumors. In this study, MVD is proposed as a predictive factor for the effectiveness of MC in canine mammary tumors. Twenty female dogs with mammary carcinoma were equally distributed into a mastectomy group treated only with mastectomy, and a MC group treated with MC (cyclophosphamide and piroxicam) orally and daily for 28 days followed by mastectomy. Mammary tumors were classified and graded histologically. MVD was ascertained by CD31 immunostaining. The analysis showed statistically significant difference in MVD scores between groups, corroborating a quantitative reduction in tumor microvasculature in the group treated with MC. Our findings suggest that MVD may be an important predictive factor for the selection of female dogs with malignant mammary tumors that may benefit from MC.
\end{abstract}

Key words: Angiogenesis. Antiangiogenic chemotherapy. Female dog. Mammary tumor.

\section{Resumo}

O tumor mamário canino é a neoplasia que mais comumente acomete cadelas não castradas na rotina veterinária. A terapia para a neoplasia mamária canina é um desafio, com poucos tratamentos eficazes descritos em medicina veterinária, especialmente para as neoplasias de alto grau. Uma opção terapêutica que diminui o crescimento tumoral é a quimioterapia metronômica (QM). A QM é uma modalidade terapêutica que age pelo decréscimo da angiogênese tumoral. Para avaliação da eficácia da QM tem sido proposta a quantificação da densidade microvascular (DMV) em neoplasias caninas. Neste

1 Discente, Curso de Doutorado, Programa de Pós-Graduação em Ciência Animal, Faculdade de Medicina Veterinária de Araçatuba, FMVA-UNESP, Araçatuba, SP, Brasil. E-mail: analymendes@hotmail.com

2 Prof., Centro Universitário de Adamantina, UNIFAI, Adamantina, SP, Brasil. E-mail: heitorferrari15@gmail.com

3 Pesquisador, Vet Path Services, Inc, Mason, Ohio, EUA. E-mail: vinicius.carreira@gmail.com

4 Discente, Programa de Residência em Medicina Veterinária, Faculdade de Medicina Veterinária de Araçatuba, FMVA-UNESP, Araçatuba, SP, Brasil. E-mail: edenilson.frigerio@hotmail.com

5 Profs., Programa de Pós-Graduação em Ciência Animal, Faculdade de Medicina Veterinária de Araçatuba, FMVA-UNESP, Araçatuba, SP, Brasil. E-mail: ruimcl@fmva.unesp.br; landrade@fmva.unesp.br

* Author for correspondence 
estudo foi proposta a mensuração da DMV como fator preditivo à utilização da $\mathrm{QM}$ em neoplasias mamárias caninas. Foram utilizadas 20 (vinte) cadelas com carcinomas mamários malignos sendo um grupo mastectomia, tratado somente por mastectomia, e um grupo QM, em que foi empregada a QM (ciclofosfamida e piroxicam) ambos oralmente e de uso diário por 28 dias seguida de mastectomia. As neoplasias mamárias foram histologicamente classificadas e graduadas. A DMV foi obtida por imunomarcação utilizando o anticorpo CD31. A análise estatística mostrou diferença na DMV entre os grupos, evidenciando redução quantitativa na microvasculatura tumoral no grupo tratado com quimioterapia metronômica. Com base neste resultado é possível afirmar que a DMV pode vir a ser um fator preditivo de importância para a seleção de cadelas portadoras de neoplasia mamária maligna que possam vir a se beneficiar da quimioterapia metronômica.

Palavras-chave: Angiogênese. Cadelas. Quimioterapia anti-angiogênica. Tumor de mama.

\section{Introduction}

Canine mammary tumors (CMT) most commonly affect intact female dogs, with a progressive increase in incidence correlating with age (EGENVALL et al., 2005). All female dogs with benign CMT and $50 \%$ of those with malignant CMT may be cured by complete surgical excision alone, while the remaining $50 \%$ with malignant tumors already have micrometastasis at the time of surgery, thereby requiring additional therapies including chemotherapy (STRAW, 2005).

Browder et al. (2000) proposed a strategy to optimize the antiangiogenic effects of conventional chemotherapy by the continuous use of certain drugs in a low-dose regimen. This treatment concept has been referred to as continuous lowdose chemotherapy, antiangiogenic chemotherapy, or metronomic chemotherapy (MC) (MUTSAERS, 2009). Clinical studies show that MC reduces the resistance to chemotherapy, offers synergism when combined with other antiangiogenic agents, and controls tumor growth through the inhibition of endothelial cells and circulating endothelial progenitor cells (BILLER, 2014).

It has been suggested that quantification of vascularization helps predict neoplastic progression and response to treatment (GASPARINI et al., 2001). For this purpose, quantification of the aspects of tumor vasculature such as microvessel density (MVD) was proposed (ARNES et al., 2012). MVD is directly related to the degree of angiogenic activity of the neoplasm, such that it can be used as a marker for the efficacy of antiangiogenic therapy and as a predictor of the effectiveness of this type of therapy, as tumors with higher vascularization are more likely to benefit from it (BIESAGA et al., 2012; HLATKY et al., 2002). The purpose of this study was to investigate the effectiveness of MVD as a predictive marker of the response of canine mammary tumors to $\mathrm{MC}$, by comparing the female dogs treated with and without MC.

\section{Materials and Methods}

Twenty $(n=20)$ female dogs with malignant mammary tumors diagnosed through cytology were used. The clinical evaluation of these animals was based on physical examination, hematological profile, serum biochemistry (urea nitrogen, creatinine, ALT, AST, ALP, protein, and albumin), urinalysis, thoracic radiographs, and abdominal ultrasound. All animals were clinically staged by the TNM system described by Owen (1980). The animals were divided into two groups. The mastectomy group (MG) $(\mathrm{n}=10)$ underwent surgical treatment which was unilateral or bilateral mastectomy. The MC group (MCG) $(\mathrm{n}=10)$ underwent $\mathrm{MC}$ followed by the same surgical treatment. The MCG underwent weekly clinical reassessment including hematologic evaluation every seven days and biochemistry every 14 days.

The animals were treated with MC for 28 days that included oral cyclophosphamide $15 \mathrm{mg} / \mathrm{m}^{2}$ 
dose $q 24 \mathrm{~h}$ with oral piroxicam $0.3 \mathrm{mg} / \mathrm{kg}$ dose $q 24 \mathrm{~h}$. Oral omeprazole $0.7 \mathrm{mg} / \mathrm{kg}$ dose $q 24 \mathrm{~h}$ was used as a gastric mucosa protector. Toxicity to chemotherapy was graded according to the Common Terminology Criteria for Adverse Events of the Veterinary Cooperative Oncology Group (MARCHETTI et al., 2012), in which high grades imply a poor quality of life.

After surgery, the mammary tumors and regional lymph nodes were trimmed and fixed in $10 \%$ buffered formalin. Regional mammary lymph nodes were trimmed and sectioned to enhance micrometastasis detection as recommended by Weaver (2010). The samples were routinely processed, sectioned at 4 $\mu \mathrm{m}$, and stained with hematoxylin and eosin (HE) (LUNA, 1968). Histological sections were examined by light microscopy (Olympus DX51, Olympus, Tokyo) by a veterinary pathologist, and mammary tumors were classified and graded according to the system given by Cassali et al. (2014).

Metastasis in regional lymph nodes was confirmed by immunohistochemical analysis with a pancytokeratin (CK) marker. The MVD score was obtained by CD31 immunostaining, as previously described by Martin et al. (1997). The immunostaining for CD31 (Clone JC70A, Abcam, dilution 1:20) and CK (AE1/AE3, Dako, dilution 1:300) were obtained using HRP polymer by the commercial detection system (Kit containing polymer Reveal, SPB-125, Spring) according to the manufacturer's recommendations.

The Mann-Whitney U-test was used for nonparametric samples. The Spearman coefficient was used to correlate MVD with clinical staging and histologic grade of mammary carcinomas. Fisher's exact test for the categorical variable of clinical staging. With a significance level of $p<0.05$, the statistical analysis was performed using the SAS ${ }^{\circledR}$ (Statistical Analysis System) computing program version 9.3 .

\section{Results}

Histopathological classification (Figure 1A) and the frequency of mammary tumors are shown in Table 1 . In the MCG, $50 \%$ of the tumors were grade I, $20 \%$ were grade II, and $30 \%$ were grade III. In the MG, $40 \%$ were grade I and $60 \%$ were grade II. Metastasis of mammary carcinoma to the regional lymph nodes was detected in three animals from each group (Figure 1B \& 1C). The MVD analysis showed a statistically significant difference in MVD between groups $(\mathrm{p}<0.05)$ (Table 2$)$, underscoring a quantitative reduction in tumor microvasculature following MC (Figure 1D). There was no correlation of MVD with histologic grade nor clinical staging.

The median age of the female dogs was 8.75 $( \pm 2.34)$; mixed breed was the most prevalent in the study (30\%), followed by the Poodle (25\%). Regarding the variables that predispose female dogs to breast cancer, $60 \%$ of the animals had a history of pseudo-pregnancy, $25 \%$ used progestogen hormones for controlling estrous, and only $10 \%$ were spayed. About $80 \%$ of the tumors were not adherent to the subjacent musculature, and $65 \%$ were less than 3 $\mathrm{cm}$ along the longest axis. Most tumors showed slow growth (75\%), and the others had a history of rapid growth (less than 1 month). Clinical staging revealed that eight $(40 \%)$ animals were at stage I, two $(10 \%)$ were at stage II, three (15\%) were at stage III, $6(30 \%)$ were at stage IV with lymph node metastasis, and one (5\%) animal was at stage $\mathrm{V}$ with lung metastasis. The animals staged at I, II, and III showed no evidence of metastasis. TNM system showed no statistically significant difference between groups.

Adverse events observed during treatment were mild and included mild episodes of nausea and emesis in six $(60 \%)$ dogs (grade I) that did not require therapeutic intervention. Diarrhea was observed in two (20\%) (grade I), with spontaneous resolution. Two (20\%) animals showed alopecia (grade I). Leukopenia by lymphopenia (grade I) 
was identified in one (10\%) animal. Similarly, serum ALT (grade I) that was controlled with elevated serum levels of urea (grade I) in one (10\%) silymarin at $30 \mathrm{mg} / \mathrm{kg}$ dose $q 24 \mathrm{~h}$ until the end of spontaneously reversed. One (10\%) had elevated MC.

Figure 1. Dog. A- Mammary squamous cell carcinoma characterized by high cellular pleomorphism, moderate mitotic index, and infiltrative behavior (200x, HE). B- Mammary regional lymph node presenting a subcapsular area of mammary carcinoma metastasis (asterisk) (40x, HE). C- Mammary regional lymph node with subcapsular carcinoma metastases, highlighted by positive immunostaining for cytokeratin AE1/AE3 (40x, DAB Hematoxylincounterstained). D- Positive immunostaining for CD31 highlighting the microvessels (400x, DAB Hematoxylincounterstained).

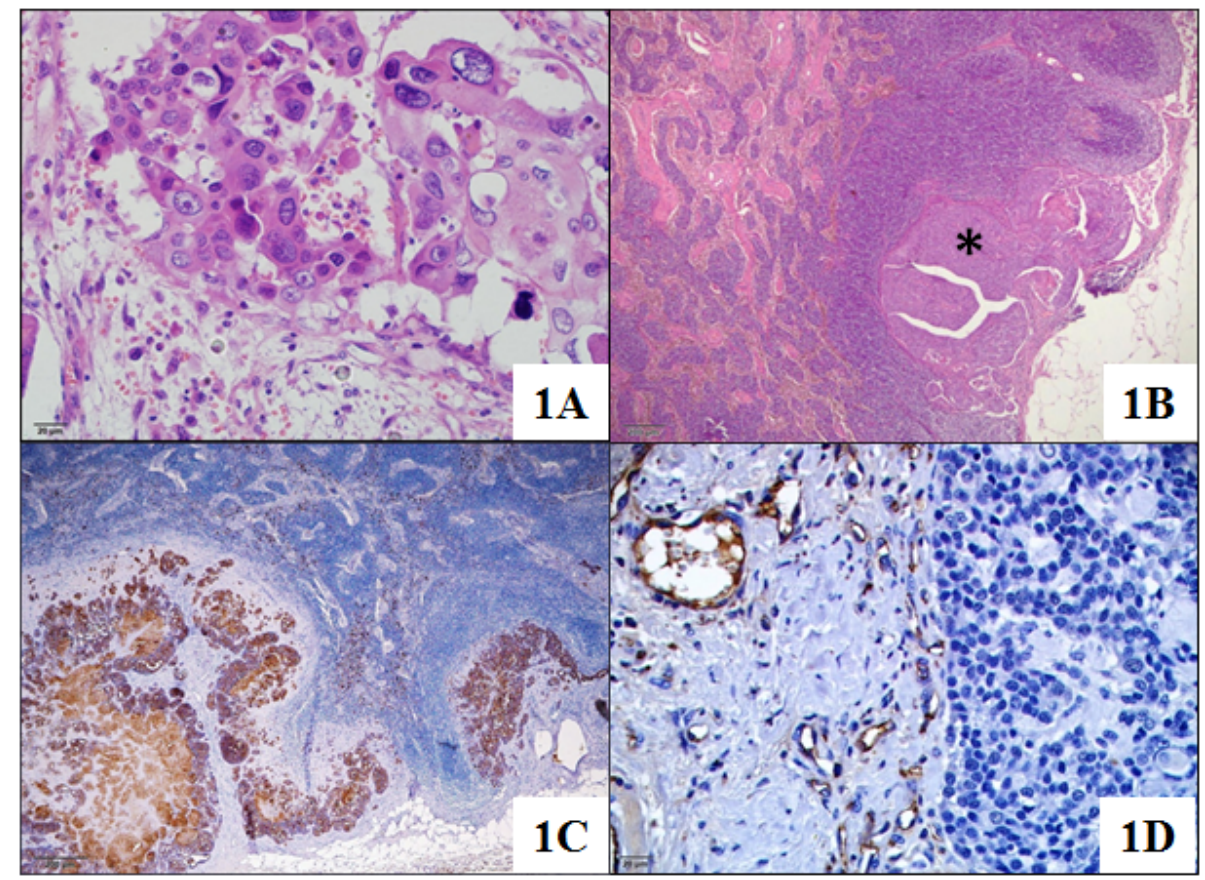

Table 1. Histopathological classification ${ }^{\mathrm{a}}$ and frequency of mammary tumors that underwent mastectomy with (metronomic chemotherapy group) or without (mastectomy group) metronomic chemotherapy.

\begin{tabular}{lcc}
\hline Histological type & Mastectomy Group & MC Group \\
\hline Carcinoma in mixed tumor & $5 \%(1)$ & $5 \%(1)$ \\
Mammary Squamous Cell Carcinoma & $0 \%$ & $10 \%(2)$ \\
Micropapillary Carcinoma & $0 \%$ & $5 \%(1)$ \\
Invasive Lobular Carcinoma & $0 \%$ & $5 \%(1)$ \\
Tubular Carcinoma & $30 \%(6)$ & $20 \%(4)$ \\
Invasive Papillary Carcinoma & $5 \%(1)$ & $5 \%(1)$ \\
Secretory Carcinoma & $5 \%(1)$ & $0 \%$ \\
\hline
\end{tabular}

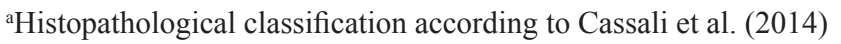

${ }^{\mathrm{b}}$ Metronomic Chemotherapy Group. 
Table 2. Mean, standard deviation (S), median (Md), minimum (Min) and maximum (Max) of CD31 variable.

\begin{tabular}{lcccc}
\hline \multirow{2}{*}{ Group } & \multicolumn{3}{c}{ CD31 } & \multirow{2}{*}{P $^{\mathbf{1}}$} \\
\cline { 2 - 4 } & Mean $\pm \mathbf{S}$ & Md & Min - Max & \\
\hline Mastectomy Group & $81,83 \pm 20,67$ & 72,95 & $61,6-116$ & \multirow{2}{*}{0,0288} \\
Metronomic Chemotherapy Group & $59,57 \pm 27,58$ & 49,3 & $31,6-110$ & \\
\hline
\end{tabular}

${ }^{1}$ Mann-Whitney test.

\section{Discussion}

High MVD has previously been associated with metastasis and poor prognosis (JAKAB et al., 2008). In oncology, a predictive marker is one that is expected to be capable of predicting the response of a patient to a particular type of therapy (SCHMITT et al., 1998). In this study, we proposed the use of the MVD score as a predictive factor of response of canine mammary carcinomas to MC. The quantitative reduction of microvessels obtained in the treated group was statistically significant, illustrating a positive response to $\mathrm{MC}$, by controlling the microvasculature of CMTs. As such, MVD may be used as a predictive factor for response to MC, since tumors with high MVD are more likely to benefit from MC.

Alow mean MVD (59.5 microvessels/200× field) was observed in the MC group, with the exception of two animals that maintained a high MVD (61 and 110 microvessels/200×). These two animals were clinically staged at stage IV, with nodal metastasis and a histopathological classification of mammary squamous cell carcinoma grade II in one patient and III in the other. Further studies involving a larger number of samples of mammary squamous cell carcinoma should be performed to ascertain the effectiveness of $\mathrm{MC}$ in the treatment of this particular histological type. Carcinoma in mixed tumor scored the lowest MVD in, which may be related to the low-grade of malignancy of this histopathological subtype. The histopathological classification as well as graduation of neoplasia are important prognostic factors. Some histological types of CMT, such as anaplastic carcinoma, micropapillary carcinoma, and mammary squamous cell carcinoma require additional therapy following surgical excision due to their particularly worse prognosis, as was corroborated in this study (CASSALI et al., 2014; MISDORP et al., 1999).

The clinical findings in the animals included in this study corroborate the notion that CMTs are hormone-dependent tumors, since $60 \%$ of the female dogs had a history of pseudo-pregnancy and $90 \%$ were intact. It has been demonstrated that early ovariectomy offers a considerable protective effect against the development of mammary carcinoma in female dogs (MISDORP et al., 1999). Moreover, pseudo-pregnancy may be a predisposing factor in adult and old female dogs (GOBELLO et al., 2001).

$\mathrm{MC}$ with the use of different chemotherapeutic drugs is a promising therapeutic modality for CMTs. Continuously administered Cyclophosphamide inhibits angiogenesis, and has a regulatory effect on antitumor immunity, promoting the depletion of regulatory $T$ cells (ELMSLIE et al., 2008). MC over long periods of time also has the potential to control the occurrence and growth of metastasis in animals at an advanced clinical stage, and it is further recommended due to its safety and minimal side effects (ELMSLIE et al., 2008).

In this study, toxicity observed in treated animals was mild. The most common clinical sign of toxicity was emesis, which occurred on the first three days of treatment, and was managed with the use of a gastric protector. No animals needed additional intervention to control emesis. Alopecia was observed in only two animals and was subjectively considered as grade I because only slight hair thinning was observed. The 
other adverse effects observed were isolated, and it was not possible to assert that they were related to MC. Sterile hemorrhagic cystitis (SHC), commonly reported with the use of cyclophosphamide, was not observed in this study. Chan et al. (2016) used furosemide concurrently with cyclophosphamide during $\mathrm{MC}$ and suggested that furosemide protects against cyclophosphamide-induced SHC.

\section{Conclusions}

MC resulted in the reduction of tumor microvasculature in canine mammary carcinomas. Our findings underscore the value of this therapeutical modality in treating CMT due to its inhibitory action on tumor angiogenesis. In the conditions adopted in this study, MVD may be used to triage those tumors with high MVD, which are more likely to benefit from MC therapy through a significant reduction of tumor microvasculature.

\section{Acknowledgements}

This study was funded by Fundacao de Amparo a Pesquisa do Estado de Sao Paulo (FAPESP) (Proc. 2013/07252-5).

\section{Bioethics and Biosecurity Committee Approval}

This study was approved by the Ethics Committee on Animal Use (CEUA) from FOA (process- FOA00496-2013).

\section{References}

ARNES, J. B.; STEFANSSON, I. M.; STRAUME, O.; BAAK, J. P.; LØNNING, P. E.; FOULKES, W. D.; AKSLEN, L. A. Vascular proliferation is a prognostic factor in breast cancer. Breast Cancer Research and Treatment, New York, v. 133, n. 2, p. 501-510, 2012. DOI: $10.1007 / \mathrm{s} 10549-011-1785-7$

BIESAGA, B.; NIEMIEC, J.; ZIOBRO, M. Microvessel density and status of $\mathrm{p} 53$ protein as potential prognostic factors for adjuvant anthracycline chemotherapy in retrospective analysis of early breast cancer patients group. Pathology and Oncology Research, Dordrecht, v. 18, n. 4, p. 949-960, 2012. DOI: 10.1007/s12253-0129525-9

BILLER, B. Metronomic chemotherapy in veterinary patients with cancer: rethinking the targets and strategies of chemotherapy. Veterinary Clinics of North America: Small Animal Practice, Amsterdam, v. 44, n. 5, p. 81729, 2014. DOI: 10.1016/j.cvsm.2014.05.003

BROWDER, T.; BUTTERFIELD, C. E.; KRALING, B.M.; SHI, B.; MARSHALL, B.; O'REILLY, M. S.; FOLKMAN, J. Antiangiogenic scheduling of chemotherapy improves efficacy against experimental drug-resistant cancer. Cancer Research, Philadelphia, v. 60, n. 7, p. 1878-1886, 2000.

CASSALI, G. D.; LAVALLE, G. E.; FERREIRA, E.; ESTRELA-LIMA, A.; NARDI, A. B. de; GHEVER, C.; SOBRAL, R. A.; AMORIM, R. L.; OLIVEIRA, L. O.; SUEIRO, F. A. R.; BESERRA, H. E. O.; BERTAGNOLLI, A. C.; GAMBA, C. O.; DAMASCENO, K. A.; CAMPOS, C. B.; ARAUJO, M. R.; CAMPOS, L. C.; MONTEIRO, L. N.; NUNES, F. C.; HORTA, R. S.; REIS, D. C.; LUVIZOTTO, M. C. R.; MAGALHÃES, G. M.; RAPOSO, J. B.; FERREIRA, A. M. R.; TANAKA, N. M.; GRANDI, F.; UBUKATA, R.; BATSCHINSKI, K.; TERRA, E. M.; SALVADOR, R. C. L.; JARK, P. C.; DELECRODI, J. E. R.; NASCIMENTO, N. A.; SILVA, D. N.; SILVA, L. P.; FERREIRA, K. C. R. S.; FREHSE, M. S.; DI SANTIS, G. W.; SILVA, E. O.; GUIM, T. N.; KERR, B.; CINTRA, P. P.; SILVA, F. B. F.; LEITE, J. S.; MELLO, M. F. V.; FERREIRA, M. L. G.; FUKUMASU, H.; SALGADO, B. S.; TORRES, $\mathrm{R}$. Consensus for the diagnosis, prognosis and treatment of canine mammary tumors - 2013. Brazilian Journal of Veterinary Pathology, Belo Horizonte, v. 7, n. 2, p. 3869, 2014.

CHAN, C. M.; FRIMBERGER, A. E.; MOORE, A. $\mathrm{S}$. Incidence of sterile hemorrhagic cystitis in tumorbearing dogs concurrently treated with oral metronomic cyclophosphamide chemotherapy and furosemide: 55 cases (2009-2015). Journal of the American Veterinary Medical Association, New York, v. 249, n. 12, p. 14081414, 2016. DOI: 10.2460/javma.249.12.1408

EGENVALL, A.; BONNETT, B. N.; OHAGEN, P.; OLSON, P.; HEDHAMMAR, A.; VON EULER, H. Incidence of and survival after mammary tumors in a population of over 80,000 insured female dogs in Sweden from 1995 to 2002. Preventive Veterinary Medicine, Amsterdam, v. 69, n. 1-2, p. 109-127, 2005. DOI: $10.1016 /$ j.prevetmed.2005.01.014 
ELMSLIE, R. E.; GLAWE, P.; DOW, S. W. Metronomic therapy with cyclophosphamide and piroxicam effectively delays tumor recurrence in dogs with incompletely resected soft tissue sarcomas. Journal of Veterinary Internal Medicine, Greenwood Village, v. 22, n. 6, p. 1373-1379, 2008. DOI: 10.1111/j.19391676.2008.0179.x

GASPARINI, G.; BIGANZOLI, E.; BONOLDI, E.; MORABITO, A.; FANELLI, M.; BORACCHI, P. Angiogenesis sustains tumor dormancy in patients with breast cancer treated with adjuvant chemotherapy. Breast Cancer Research and Treatment, New York, v. 65, n. 1, p. 71-75, 2001. DOI: 10.1023/A:1006476401801

GOBEllo, C.; DE LA SOTA, R. L.; GOYA, R. G. A review of canine pseudocyesis. Reproduction in Domestic Animals, Oxford, v. 36, n. 6, p. 283-288, 2001. DOI: $10.1046 /$ j.1439-0531.2001.00322.x

HLATKY, L.; HAHNFELDT, P.; FOLKMAN, J. Clincal application of antiangiogenic therapy: microvessel density, what it does and doesn't tell us. Journal of the National Cancer Institute, Oxford, v. 94, n. 12, p. 883893, 2002. DOI: 10.1093/jnci/94.12.883

JAKAB, C.; HALÁSZ, J.; KISS, A.; SCHAFF, Z.; SZÁSZ, A. M.; RUSVAI, M.; TÓTH, Z. A.; KULKA, J. Evaluation of microvessel density (MVD) in canine mammary tumours by quantitative immunohistochemistry of the claudin-5 molecule. Acta Veterinaria Hungarica, Budapest, v. 56, n. 4, p. 495-510, 2008. DOI: 10.1556/ AVet.56.2008.4.7

LUNA, L. G. Rotine staining procedures. In: LUNA, L. G. (Ed.). Manual of histologic staining methods of the armed forces institute of pathology. New York: McGraeHill Book, 1968. cap. 4, p. 32-46.

MARCHETTI, V.; GIORGI, M.; FIORAVANTI, A.; FINOTELLO, R.; CITI, S.; CANU, B.; ORLANDI, P.;
DI DESIDERO, T.; DANESI, R.; BOCCI, G. First-line metronomic chemotherapy in a metastatic model of spontaneous canine tumours: a pilot study. Investigational New Drugs, New York, v. 30, n. 4, p. 1725-1730, 2012. DOI: $10.1007 / \mathrm{s} 10637-011-9672-y$

MARTIN, L.; GREEN, B.; RENSHAW, C.; LOWE, D.; RUDLAND, P.; LEINSTER, S. J.; WINSTANLEY, J. Examining the technique of angiogenesis assessment in invasive breast cancer. British Journal of Cancer, London, v. 76, n. 8, p. 1046-1054, 1997. DOI: 10.1038/ bjc. 1997.506

MISDORP, W.; ELSE, R. W.; HELLMÉN, E.; LIPSCOMB, E. Who histological classification of mammary tumors of the dog and cat. Washington: Armed Forces Institute of Pathology, 1999. 58 p.

MUTSAERS, A. J. Metronomic chemotherapy. Topics in Companion Animal Medicine, Amsterdam, v. 24, n. 3, p. 137-143, 2009. DOI: 10.1053/j.tcam.2009.03.004

OWEN, L. N. The TNM classification of tumors in domestic animals. Geneva: World Health Organization, $1980.53 \mathrm{p}$.

SCHMITT, F. C.; SOARES, R.; CIRNES, L.; SERUCA, R. P53 in breast carcinomas: association between presence of mutation $\mathrm{n}$ and immunohistochemical expression using a semiquantitative approach. Pathology - Research and Practice, Amsterdam, v. 194, n. 12, p. 815-819, 1998. DOI: 10.1016/S0344-0338(98)80083-6

STRAW, R. C. Treatment of mammary gland tumors and perianal neoplasia. In: THE NORTH AMERICAN VETERINARY CONFERENCE, 2005, Orlando. Proceedings... Orlando: NAVC, 2005. p. 672-675.

WEAVER, D. L. Pathology evaluation of sentinel lymph nodes in breast cancer: protocol recommendations and rationale. Modern Pathology, London, v. 23, n. 2, p. 2632, 2010. DOI: $10.1038 /$ modpathol.2010.36 
